focus on German Studies.

https://journals.uc.edu/index.php/fogs

(ISSN 1076-5697)

focus

on German Studies

Issue 27 (2020)

Book Review

Kaliningrad and Cultural Memory: Cold War and Post-Soviet Representations of a

Resettled City

by Edward Saunders, Peter Lang, 2019. 308 pp $\$ 96.85$

Peter Gengler

Duke University

How to Cite: Gengler, Peter. "Book Review: Kaliningrad and Cultural Memory: Cold W ar and Post-Soviet Representations of a Resettled City

by Edward Saunders". focus on German Studies 27: Spielformen des Authentischen, no. 27, 2020, pp. 117-123. doi:

10.34314/FOGS2020.000014. 


\section{Kaliningrad and Cultural Memory: Cold War and Post-Soviet Representations of a}

\section{Resettled City}

\section{by Edward Saunders, Peter Lang, 2019. 308 pp $\$ 96.85$}

Peter Gengler

When one hears "Kaliningrad," most will probably think of a vague port city somewhere on the Baltic, while the word "Königsberg" holds even greater mystery. Many Germans can only vaguely place the former Prussian city, home of Hohenzollern rulers and Immanuel Kant, and birthplace of the culinary delight of Königsberger Klopse. Locked behind the Iron Curtain for decades and surviving only in the incomprehensible memories of surviving elderly relatives, Königsberg and most of the German East have become an enigma, evoking feelings of nostalgia, confusion, and disdain. Likewise, Russians hold ambivalent feelings toward Kaliningrad. A military city and collection of barracks, cut off from Russia, historically a source of suspicion of and admiration for Western achievementlike Königsberg for Germans, Kaliningrad is many things to many Russians, and more often than not they have a distorted image.

How can one unravel this nexus of fact and myth, of memory and imagination, all in one city with a contested past and uncertain future? Edward Saunders, a literary and cultural historian at the Webster Vienna Private University, seeks to make sense of the conflicting and fascinating place Königsberg/Kaliningrad holds in the minds of former German and current Russian inhabitants. As a specialist in comparative literature and a focus on Central and Eastern Europe, Saunders' training and background suit him well for the multidisciplinary investigation he attempts here. His previous research included a biography of Arthur Koestler, and he co-edited a volume on the short-lived Hungarian Soviet Republic of 1919 and how it was reflected in biographies and literature. 
Saunders broadly attempts to demystify Königsberg/Kaliningrad, and to scrutinize the clichés and distortions by analyzing "how the city's history is imagined and remembered as part of the peripheries of both Western and Eastern Europe (3)" from 1945 into the present. Saunders is interested in the evolving significance of the city as a cultural memory site in literature, film, photography, and other visual culture, as well as the issue of nostalgia. The "mythographical" mapping of the discursive development of the city's symbolism, Saunders argues, represent the original aspects of his study and the most significant contribution of his research.

In order to make his case, Saunders divides his book into three parts, each with three chapters. Part I focuses on historical context of Königsberg/Kaliningrad as a memory site and explores the debates over history and memory of the Baltic city. A chapter on Königsberg as a memory site for expellees is followed by a section on renaming debates after WWII and attempts of Russians to transform a German object of conquest into Soviet colony and home. The last chapter of this part looks at the loss of "cultural intimacy" (69) that the war and forced migrations produced, and contemplates the confusion of emotions (e.g. nostalgia, dismay, curiosity) that both Germans and Russians associate with Königsberg/Kaliningrad.

In Part II, Saunders examines on "Kant in Königsberg," as the philosopher is inextricably bound to that city. Chapter 4 outlines Kant's "biomyth" and the subversion of the figure through satires by Thomas Bernhard and Frédéric Pagés. Next, an analysis of a play by Bertholt Brecht argues that here Kant served as the backdrop for a revisit of "German misery" and celebration of East Germany's foundation. Lastly, Saunders explores how Johannes Bobrowski's childhood home and nostalgic remembrances of Königsberg influenced his fascination for Johann Georg Hamann, a critic of Kant's Enlightenment rationality. 
In the last part of the book, Saunders uses writings, film, and photography to contemplate how memories of the past relate to the present and visions of the future. One chapter engages in a close reading of the poems of Joseph Brodsky, while another chapter uses the poetry of Tomas Venclova and Šarunas Bartas' film Three Days to reflect on themes of despair and tragedy associated with Kaliningrad in the perestroika and post-Soviet era. Lastly, the photographic series of Joachim Koester and Norbert Wiesneth cast a light on how Kaliningrad is imagined in the age of Putin, focusing in particular on the "ruin aesthetics" that explore a traumatic and fragmented German and Soviet past.

There are many achievements that Saunders can lay claim to. To begin with, the study puts a magnifying glass to a city that remains a mystery for many Westerners, though it played a pivotal role in German and European history for centuries. Indeed, that is part of the entire raison d'etre of the study: to rescue Königsberg/Kaliningrad from obscurity after it disappeared behind the Iron Curtain and reconstruct the many complicated and different ways Russians and Germans remember, imagine, and currently see the city. Inviting readers to travel through time and the myriad layers of emotions and memories, Saunders has resurrected various incarnations of the Prussian metropolis and opened a forgotten chapter of European history and culture.

The careful attention that Saunders devotes to the fluctuating way in which Königsberg/Kaliningrad manifested itself is another commendable success of this study. Saunders captures the tension between the city as Germany's easternmost and Russia's westernmost outpost. But Saunders also peels back the layers that have shaped the place of Königsberg/Kaliningrad in German and Russian memory, convincingly showing how the Enlightenment, Third Reich, ethnic cleansing and resettlement, communism, and postcommunism have shaped the city, and with it, perceptions of it. While historians may quibble over Saunders' tendency to give context short shrift or simplify or overlook crucial 
historical developments, the generally nuanced view spanning several centuries successfully argues the evolution of memory of Königsberg/Kaliningrad.

Lastly, Saunders marshals literature, memoirs, art, film, and academic studies from several disciplines to create an impressive tableau. Readers will be charmed by the ease with which he draws from diverse wells to make his argument. The mastery of his sources, as well as the erudite interpretation and analysis of them, reveal the intellectual acumen of the author.

Despite these achievements, the study also suffers from some deficiencies. This is not the easiest read. The intellectual density and heavy focus on theory suggest that few readers beyond academia will find the study accessible. Occasionally verbose passages and heavy jargon demand an informed reader familiar with the conventions of Saunders' discipline. The organization of the study also could have been stronger. It sometimes reads as a collection of essays, with the result that the study meanders and feels disjointed. Individually, the parts fulfill their intended goal; together, it is not clear how they relate to one another, and what story Saunders is attempting to tell. This means that at times, the argumentative thread gets lost or buried under a collage of different vignettes of Königsberg/Kaliningrad. Saunders is attempting to create a kaleidoscope of impressions, but a more sustained organizing principle would have helped readers venture through the dense intellectual terrain.

In addition to feeling occasionally disconnected, the text also comes across as uneven. There are sections that are magnificent and captivating, such as when Saunders describes Russians (re)discovering Königsberg and coming to terms with a city that was foreign and home all at once. Elsewhere, Saunders paints evocative scenes of how expelled Germans wrestled with nostalgia and the loss of their homeland. These are compelling passages, and Saunders is at his best when he eschews theory and delivers an empirical account of the conflicting, contrary, and ambivalent memories associated with this contested memory site. 
focus on German Studies.

https://journals.uc.edu/index.php/fogs

(ISSN 1076-5697)

focus

on German Studies

Yet for all of these charming moments, there are others that seem tenuous detours. In Saunders' "Kant in Königsberg" section, for example, readers may wonder with ruminations over "metabiography" and "biomyth" whether Saunders is trying to unravel the memory of the philosopher instead of the city.

A last shortcoming is related to Saunders' tendency of engaging in extensive contemplation of esoteric texts. Saunders himself freely admits that his discipline and approach favor "works of greater aesthetic, intellectual or philosophical merit and sophistication" (8). If the study seeks to outline cultural and collective memory, it is doubtful that high culture will provide the necessary insights. Just exactly whose memory is Saunders interested in?

By privileging how artists and intellectuals remember Königsberg/Kaliningrad, it glosses over how many thousands of "ordinary" former and current residents view their homeland. Why does Brecht hold more insight than, say, the images of a romanticized and idealized homeland in the ubiquitous Heimatbücher of the 1950s and 60s? The wartime accounts of Hans von Lehndorff that dominated bestseller charts in West Germany may have opened important perspectives as well. In other words, much of the memories Saunders traces are not reflective of how the vast majority of Königsbergers/Kaliningraders feel. ${ }^{1}$ Germans contemplated the German East a lot, and it was these iterations that left lasting impressions on German memory. To put it succinctly: Saunders undertakes a study of cultural memory, but a particular and elitist vantage point.

Despite these criticisms, Saunders delivers a convincing dynamic panorama of various

\footnotetext{
${ }^{1}$ As a counterpoint, see historical studies that examine the memory of the expulsions and multiple ways in which Germans have mourned, contemplated, and imagined their homeland. See Andrew Demshuk, The Lost German East: Forced Migration and the Politics of Memory, 1945-1970 (Cambridge: Cambridge University Press, 2012). See also Maren Röger, "Ereignis- und

Erinnerungsgeschichte von „Flucht und Vertreibung“. Ein Literaturbericht,” Zeitschrift für Geschichtswissenschaft 62, no. 1 (2014): 4964; Stephan Scholz, Maren Röger, and Bill Niven, eds., Die Erinnerung an Flucht und Vertreibung: ein Handbuch der Medien und

Praktiken (Paderborn: Schöningh, 2015).
} 
impressions and imaginings of Königsberg/Kaliningrad spanning several centuries. Even if it is a selective perspective, Saunders succeeds in making his greater point: this city, caught between East and West, is a fascinating and unique "multivalent memory site" (89). The selection of a wide range of sources will offer bits and pieces for literary scholars, as well as historians. In particular, Saunders' research reminds of other studies with similar interests, and makes a welcome addition. ${ }^{2}$ It is for this reason that Saunders deserves admiration for having produced a remarkable study and having provided a crucial point of departure for further research.

\footnotetext{
2 See for instance Gregor Thum, Uprooted: How Breslau Became Wrockaw during the Century of Expulsions (Princeton: Princeton University Press, 2011).
} 